\title{
Pemanfaatan E-Learning Sebagai Media Pembelajaran Pada Program Studi PPKn Universitas Quality
}

\author{
Krista Surbakti1), Manitron Bangun²), Elviany Br Barus ${ }^{3)}$
}

Email: kristasurbakti84@gmail.com

\begin{abstract}
Abstrak
Penelitian ini bertujuan untuk mendeskripsikan pemanfaatan e-learning sebagai media pembelajaran dan faktor-faktor apa saja yang dapat mempengaruhinya pada Program Studi PPKn FKIP Universitas Quality, mahasiswa Semester Program Studi Pendidikan Pancasila dan Kewarganegaraan pada Fakultas Keguruan dan Ilmu Pendidikan Universitas Quality di masa pandemi covid-19. Jenis penelitian yang digunakan dalam penelitian ini adalah penelitian deskriptif dan subjek dalam penelitian ini adalah mahasiswa semester dua yang sedang mengikuti mata kuliah perkembangan peserta didik pada Program Studi PPKn Fakultas Keguruan dan Ilmu Pendidikan Universitas Quality. Instrumen yang akan digunakandalam penelitian ini yaitu kuisioner yang disebarkan kepada mahasiswa dalam satu kelas yang berjumlah 8 mahasiswa dan nalisis data yang digunakan adalah analisis deskriptif. Untuk menguji hipotesis digunakan uji t-test dan hipotesis menunjukkan bahwa terdapat pengaruh signifikan terhadap kreatifitas mahasiswa dengan memanfaatkan e-learning sebagai media pembelajaran dimasa pandemi covid-19. Hasil penelitian harus bermanfaat bagi masyarakat luas
\end{abstract}

Kata Kunci : E-learning, Media Pembelajaran, Mahasiswa 


\section{Pendahuluan}

A. Latar Belakang Penelitian

Untuk dapat mengetahui, memahami dan melakukan hal yang tadinya belum diketahui, dipahami dan tidak dapat dilakukan, merupakan proses belajar seseorang. Proses belajar yang kurang maksimal dapat menyebabkan hasil belajar yang kurang maksimal. Hasil belajar adalah kemampuan-kemampuan yang dimiliki siswa setelah ia menerima pengalaman belajarnya. Pengalaman belajar siswa diperoleh dari proses belajar siswa, maka proses belajar siswa dapat mempengaruhi hasil belajar siswa. Mahasiswa dalam belajar membutuhan motivasi yaitu suatu dorongan atau kekuatan yang menyebabkan mahasiswa mempunyai keinginan untuk melakukan kegiatan belajar. Dosen memiliki peranan penting dalam menumbuhkan motivasi belajar Mahasiswa. Dosen dapat menciptakan pembelajaran yang menarik sehingga dapat menumbuhkan motivasi belajar Mahasiswa dan media pembelajaran dapat digunakan untuk membantu Dosen menciptakan pembelajaran yang menarik.

Pembelajaran saat ini, lebih diarahkan pada aktivitas modernisasi dengan bantuan teknologi canggih, apa lagi di masa pandemi corona (Covid-19) ini dengan harapan dapat membantu

mahasiswa dalam mencerna materi perkuliahan secara interaktif, produktif, efektif, inspiratif, konstruktif, dan menyenangkan. Selain itu, mahasiswa juga diharapkan memiliki life skill dari aplikasi teknologi tersebut.

Dengan adanya era teknologi yang semakin berkembang ini maka progam pembelajaran diarahkan untuk bisa memanfaatkan teknologi dengan lebih baik. Salah satu pemanfaatan teknologi saat ini adalah $e$-Learning menggunakan web untuk mengaksesnya. Tidak memungkiri karena banyak mahasiswa sekarang memiliki smart phone jadi lebih mudah untuk mengaksesnya dari manapun berada dan kapanpun juga. Pemanfaatan e- learning yang biasa dikembangkan saat ini adalah menggunakan LMS (Learning Management System).

Universitas Quality merupakan salah satu Perguruan Tinggi yang telah memanfaatkan e- Learning sebagai media pembelajaran pada masa pandemi covid19. Kegiatan pembelajaran menggunakan media e-learning di kampus tersebut adalah memanfaatkan aplikasi moodle. Dalam proses pembelajaran mahasiswa diberikan penugasan oleh dosen dan mengirimkan hasil laporannya ke elearning. Selain itu juga mahasiswa diberikan materi tambahan guna memahami lebih luas materi yang mungkin belum bisa tersampaikan 
langsung ketika tatap muka di kelas. Elearning merupakan media alternatif untuk memberikan soal-soal ujian test dan impovisasi media yang tidak selalu menggunakan media cetak apalagi dimasa pandemi corona (Covid-19) ini, elearning sangat bermanfaat bagi mahasiswa.

B. Identifikasi Masalah

Berdasarkan latar belakang diatas maka dapat diidentifikasi beberapa permasalahansebagai berikut:

1. Kegiatan belajar mengajar secara tatap muka tidak efektif

2. Dosen tidak bisa memberikan materi secara lansung kepada mahasiswa di kelas

3. Mahasiswa kurang termotivasi dalam belajar

4. Hasil belajar mahasiswa rendah

5. Kurangnya pemahaman mahasiswa terhadap pembelajaran yang diberikan dosen.

C. Rumusan Masalah Dan Tujuan Penelitian

Berdasarkan latar belakang di atas, rumusan masalah dalam penelitian ini adalah bagaimanakah manfaat e-learning sebagai media pembelajaran terhadap motivasi belajar dalam meningkatkan hasil belajar mahasiswa di semester II Program Studi PPKn Fakultas Keguruan dan Ilmu Pendidikan Universitas Quality?

D. Tujuan Khusus

1. Mengamati mahasiswa dalam menerima pelajaran yang diberikan oleh dosen
2. Melaksanakan PBM dengan menggunakan aplikasi google classroom di kelas

\section{E. Urgensi Penelitian}

Penelitian ini akan menghasilkan pengetahuan bahwa aplikas google class room sangat baik digunakan oleh dosen dan mahasiswa dalam pelaksanann proses belajar mengajar dengan baik pada masa pandemi corona (covid-19).

\section{Tinjauan Pustaka}

1. Pengertian E-Learning

E-learning merupakan singkatan dari elektronic learning, yaitu proses pembelajaran yang menggunakan media elektronik khususnya internet sebagai sistem pembelajarannya. Elearning merupakan dasar dan konsekuensi dari perkembangan teknologi informasi dan komunikasi. Bullen \& Janes (2011:176) mendefinisikan e-learning sebagai pembelajaran yang terjadi ketika teknologi internet digunakan untuk memfasilitasi, menyampaikan, dan memungkinkan proses pembelajaran dengan jarak yang jauh. Definisi yang lebih umum dikemukakan oleh Freire \& Pereira (2012) yaitu elearning merupakan pembelajaran pada program pendidikan atau pelatihan melalui sarana elektronik. Naidu (2013:1) mengatakan "Elearning is commonly referred to the 
intentional use of networked information and communications technology in teaching and learning”. E- learning juga merupakan sebuah proses pembelajaran berbasis elektronik. Salah satu media yang digunakan adalah jaringan komputer. Dengan demikian memungkinkan untuk dikembangkan dalam bentuk web. Penyajian e-learning berbasis web bisa menjadi lebih interaktif. Informasi-informasi mengenai perkuliahan juga bisa real-time. Begitu juga dengan komunikasi, meskipun tidak secara langsung tatap muka, tapi forum diskusi perkuliahan bisa dilakukan secara online dan real time. Dimana sistem e-learning tidak memiliki batasan akses, inilah yang memungkinkan perkuliahan bisa dilakukan lebih banyak waktu. Kapanpun dan dimanapun asalkan tersedia jaringan internet mahasiswa bisa mengakses sistem ini.

2. Pengertian belajar

Belajar adalah suatu aktivitas atau proses untuk memperoleh pengetahuan, meningkatkan keterampilan, memperbaiki perilaku,sikap, dan mengokohkan kepribadian. Belajar merupkan suatu proses suatu kegitan dan bukan suatu hasil atau tujuan. Belajar bukan hanya mengingat. Dengan belajar manusia dapat melakukan perubahan-perubahan pada dirinya sehingga tingkahlakunya dapat berkembang.

3. Pengertian Mengajar

Menurut Sanjaya (2012:96), menyatakan bahwa "mengajar adalah sebagai proses penyampaian informsi atau pengetahuan dari guru kepada siswa. Menurut Defenisi dari Dequeliy dan Gazali, dalam Slameto (2015:30), Menyatakan bahwa "mengajar adalah menanamkan pengetahuan pada seseorang dengan cara paling singkat dan tepat". Menurut Waini Rasyidin (Slameto, 2011: 34) "Mengajar adalah partisipasi guru dan siswa satu sama lain. Guru merupakan koordinator, yang melakukan aktivitas dalam intraksi sedemikian rupa, sehingga siswa belajar seperti yang kita harapkan. Guru hanya menyusun dan mengatur situasi belajar dan bukan menentukan proses belajar".

4. Pengertian pembelajaran

Menurut Winkel dalam (Eveline Siregar dan Hartini Nara, 2011:12) "Pembelajaran adalah seperangkat tindakan yang dirancang untuk mendukukung proses belajar siswa, dengan mempehitungkan kejadiankejadian ekstrim yang berperan 
terhadaprangkaian kejadian-kejadian intern yang berlangsung dialami siswa". Sementara menurut Miarso (Eveline Siregar dan Hartini Nara, 2011:12) menyatakan bahwa “ pembelajaran adalah usaha pendidikan yang dilaksanakan secara sengaja,dengan tujuan yang telah ditetapkan terlebih dahulu sebelum proses dilaksanakan, serta pelaksanaanya terkendali".

5. Pengertian Hasil Belajar

Menurut Winkel (Purwanto, 2011:45) "Hasil belajar adalah perubahan yang mengakibatkan manusia berubah dalam sikap dan tingkah lakunya”. Menurut Benyamin

S. Bloon (Asep Jihad dan Abdul Haris, 2013:14) berpendapat bahwa "hasil belajar dapat diklompokkan ke dalam dua macam yaitu pengetahuan dan keterampilan". Sedangkan Sudjana (Asep Jihad dan Abdul Haris, 2013:15) berpendapat "hasil belajar adalah kemampuankemampuan yang dimiliki siswa setelah ia menerima pengalaman belajarnya".

6. Pengertian Media Pembelajaran Istarani (2011:1) berpendapat bahwa media pembelajaran adalah seluruh rangkaian pembelajran materi ajar yang meliputi segala aspek sebelum dan sesudah pembelajaran yang dilakukan guru serta segala fasilitas yang terkait yang digunakan secara langsung atau tidak langsung dalam proses belajar mengajar.

7. Road Map Penelitian

Road Map penelitian yang akan dilakukan memiliki tiga tahapan yaitu perencanaan, pelaksanaan dan monev (monitoring dan evaluasi) dimana perencanaan yaitu padaide/gagasan dan pembuatan proposal penelitian, pelaksanan pada saat melakukan penelitian serta analisis data penelitian, dan monev pada saat penelitian harus dikaji ulang agar tidak terjadi kesalahan data dan sesuai dengan target luaran penelitian.

\section{Metode Penelitian}

A. Lokasi Penelitian

Penelitian ini dilaksanakan di Prodi

PPKn Fakultas Keguruan dan Ilmu

PendidikanUniversitas Quality.

B. Subjek Penelitian

Subjek penelitian adalah mahasiswa Prodi PPKn semester II mata kuliah perkembanganpeserta didik.

C. Jenis Penelitian

Jenis penelitian ini adalah penelitian kualitatif yang bertujuan untuk mengetahui manfaat e-learning sebagai media pembelajaran.

D. Tugas Peneliti

Penelitian ini memiliki beberapa 
tahapan pelaksanaan yang dilangsungkan di dalam kelasonline, yaitu melakukan Perencanaan, Pengamatan dan Pelaksanaan yang dilakukan oleh peneliti.

\section{Diagram Alir Penelitian}

Metodologi penelitian bertujuan untuk menyelesaikan masalah yang ada secara terstruktur.Berikut pembagian dari flow chart penelitian ditunjukkan dalam gambar dibawah ini.Persiapan pembuatan lembar observasi

Peneliti melakukan persiapan mengenai lembar observasi.

Pembuatan lembarobservasi yang merupakan perangkat dari penelitian yang dilakukan agar data yang diperoleh relevan dan valid.

A. Mempersiapkan responden dan sampel

Hal ini dilakukan agar data yang diperoleh langsung diambil dari para responden yang dikjadikan sampel dalam penelitian ini.

B. Melakukan Observasi

Dilakukan pada saat penelitian ini dilaksanakan ketempat lokasi penelitian yaitu prodiPPKn FKIP Universitas Quality berada.

C. Pembuatan Laporan dan Analisis Dilakukan pada saat melakukan penelitian dan setelah penelitian dilapangan. Data yang telah didapatkan akan di analisis sesuai dengan metode penelitian yang sudah di buat.

D. Hasil

Setelah melakukan analisis data maka diperoleh hasil yang valid dari penelitian yang telah dilakukan, ditahap ini kesimpulan dari penelitian adalah klimaks dari laporan hasil penelitian.

E. Jurnal Nasional Sinta 6-3

Adalah luaran wajib yang harus dilakukan yaitu publikasi pada jurnal terindeks Sinta 6-3 dimana Sinta 6 adalah target terendah dari luaran wajib penelitian ini.

\section{Hasil dan Pembahasan}

\section{A. Hasil}

1. Karakteristik Responden

Karakteristik responden dalam penelitian ini antara lain jenis kelamin, fakultas, waktu penggunaan internet dalam sehari, dan tempat menggunakan internet.

1) Jenis Kelamin: dari 100 responden yang ada terdiri dari 2 laki-laki dan 2 perempuan.

2) Waktu Penggunaan Internet dalam Sehari; waktu penggunaan internet dalam sehari responden 22\% kurang dari 1 jam. Untuk penggunaan 
internet 1 sampai dengan 2 jam sehari frekuensinya sebesar $44 \%$. Selanjutnya $18 \%$ untuk penggunaan internet 2 sampai dengan 3 jam sehari dan $16 \%$ untuk penggunaan lebih dari 3 jam sehari dari total responden yang ada.

3) Tempat Menggunakan Internet; Frekuensi penggunaan internet $46 \%$ dilakukan responden di warung internet, $31 \%$ dilakukan di rumah dan $23 \%$ dikampus.

2. Deskripsi Variabel Pemanfaatan Elearning Secara Keseluruhan

Pada penyajian tabel dibawah ini, dapat di jelaskan bahwa jumlah pertanyaan yang terdapat pada kuisioner berjumlah 16 pertanyaan dari 8 dimensi. Sedangkan alternatif jawaban terhadap pertanyaan terdiri dari 5 alternatif jawaban, yaitu : nilai 1 untuk tingkat yang sangat tidak baik, nilai 2 untuk tingkat yang tidak baik, nilai 3 untuk tingkat yang cukup baik, nilai 4 untuk tingkat yang baik, nilai 5 untuk tingkat yang sangat baik

\section{B. Pembahasan}

1. Pemanfaatan E-learning sebagai Media Pembelajarandi Universitas Quality Berdasarkan pada hasil pengolahan data yang telah dilakukan terhadap data yang

diperoleh secara langsung dari responden maka dapat dijelaskan bahwa kondisi pemanfaatan e-learning sebagai media pembelajaran di Universitas Quality berada pada kondisi baik dengan total persentase sebesar $60 \%$ dengan indikator berupa tingkat persentase sebesar $28.5 \%$ cukup baik, didukung dengan persentase kondisi baik sebesar $21.6 \%$ dan kondisi sangat baik dengan $10.1 \%$.

Namun dalam proses pemanfaatan e-learning sebagai media pembelajaran di Universitas Quality harus terus ditingkatkan dengan memaksimalkan semua dimensi dari karakteristik elearning yang ada.

2. E-learning Universitas Quality berdasarkan 8 Karakteristik e-learning

Dari penyajian pada Tabel II, dapat diketahui bahwa dari 8 dimensi atau faktor dari e- learning Universitas Quality baru empat faktor yang sudah baik kondisinya yaitu Non- Linerity, Self-Managing, Just in Time, dan Easy Accesbility. Kondisi ini menunjukan bahwa pemanfaatan e-learning sebagai media pembelajaran di Universitas Quality untuk faktor kebebasan pemakai (user) dalam mengakses objek pembelajaran. Kemampuan dosen dalam mengelola sendiri proses pembelajaran dengan mengikuti struktur yang telah 
dibuat, dan waktu terhadap pengaksesan e-learning serta kemudahan dalam mengakses e-learning sudah cukup baik.

Sedangkan untuk faktor FeedbackInteractivity, Multimedia-Learners style, Dynamic updating, dan Colaborative Learning belum baik kondisinya. Hal ini menunjukan bahwa e- learning Universitas Quality belum terjadi proses interaksi secara interaktif, belum terdapat materi pembelajaran berbasis multimedia dan isi atau materi e-learning tidak sering diperbaharui, serta proses pembelajaran tidak dilakukan secara kolaboratif.

\section{Kesimpulan dan Saran}

Berdasarkan analisa dan hasil pembahasan yang telah dilakukan dikaitkan dengan rumusan masalah dan tujuan yang telah ditetapkan, maka dapat diambil kesimpulan sebagai berikut :

1) Pemanfaatan e-learning sebagai media pembelajaran berada pada kondisi cukup baik, dibuktikan dengan hasil pengolahan terhadap data yang diperoleh langsung dari para responden dengan persentase sebesar $28.5 \%$, kondisi baik $21.6 \%$ dan $10.1 \%$ sangat baik. Hal ini membuktikan bahwa mahasiswa termotivasi dengan proses pembelajaran

dengan menggunakan media e- learning dan meningkatkan kualitas pembelajaran yang dilaksanakan serta hasil belajarnya.

2) Dari delapan karakteristik sebuah elearning yaitu Non-linearity, Selfmanaging, Feedback-interactivity, Multimedia-Leaners style, Just in Time, Dynamic Updating, Easy Accesibility dan Colaborative Learning, hanya di dimensi Nonlinearity, Self- managing, Just in Time, dan Easy Accessibility berada di kondisi cukup baik, sedangkan dimensi yang lain masih berada di kondisi belum baik.

3) Untuk pengembangan e-learning Universitas Quality,maka karakterisik e-learning yang belum baik, untuk lebih ditingkatkan lagi sehingga tujuan dibangun dan digunakannya e-learning sebagai media pembelajaran dapat benarbenar dirasakan oleh civitas Universitas Quality. Diperlukan dukungan sepenuhnya dari seluruh civitas Universitas Quality dalam pemanfaatan e-learning sebagai media pembelajaran baik dalam bentuk instruksi maupun kebijakan.

\section{Daftar Pustaka}

Burhanuddin, K. (2013) Penggunaan elearning sebagai media pembelajaran. Jurnal Pendidikan Ekonomi: Jurnal 
Ilmiah Ilmu Pendidikan, Ilmu Ekonomi dan Ilmu Sosial, 10(1).

Falahudin, I. (2014). Pemanfaatan media dalam pembelajaran. Jurnal Lingkar Widyaiswara, 1(4), 104-117.

Hakim, L., \& Agung, H. (2018). Kajian Desain E-Learning Universitas Bunda Mulia Berdasarkan Spesifikasi ELearning. Prosiding Semnastek.Hartanto, W. (2016).

Hayati, S., Budi, A. S., \& Handoko, E. (2015, October). Pengembangan media pembelajaran flipbook fisika untuk meningkatkan hasil belajar peserta didik. In Prosiding Seminar Nasional Fisika (EJournal) (Vol. 4, pp. SNF2015-II).

Islamiyah, M., \& Widayanti, L. (2016). Efektifitas Pemanfaatan E-Learning Berbasis Website Terhadap Hasil Belajar Mahasiswa STMIK Asia Malang Pada Mata KuliahFisika Dasar. Jurnal Ilmiah Teknologi Informasi Asia, 10(1), 41-46.

Khoiroh, N., Munoto, D., \& Anifah, L. (2017). Pengaruh Model Pembelajaran Blended Learning Dan Motivasi Belajar Terhadap Hasil Belajar Siswa. Jurnal Penelitian Ilmu Pendidikan, 10(2), 97-110. Satryawan, G. N. W., Darmawiguna, I. G. M., \& Sunarya, I. M. G. (2014). Pengembangan Media Belajar Pupuh Berbasis Android. Jurnal Pendidikan Teknologi dan Kejuruan, 11(2),92-103. Solichah, I. (2014). Alat peraga untuk pelajar tunarungu: Penggunaan bentuk dua dimensi bangun datar pada siswa tunarungu. Media Guru.

Wisnu Wirawan, P. (2011). Pengembangan Kemampuan E-Learning Berbasis Web ke dalam M Learning. Jurnal Masyarakat Informatika, 2(4).

Alkaff, A. (2015). Pengaruh Penggunaan Internet sebagai Media Belajar Terhadap Prestasi Belajar Mahasiswa Prodi Ilmu Administrasi Negara Fisip Di Universitas Islam jember. Jurnal Paradigma Madani, 2(2), 127-154. 